\title{
Koffie, kool en de mogelijkheden van voedingsvoorlichting
}

Citation for published version (APA):

Brug, J. (2000). Koffie, kool en de mogelijkheden van voedingsvoorlichting. Universiteit Maastricht. https://doi.org/10.26481/spe.20000908jb

Document status and date:

Published: 08/09/2000

DOI:

10.26481/spe.20000908jb

Document Version:

Publisher's PDF, also known as Version of record

\section{Please check the document version of this publication:}

- A submitted manuscript is the version of the article upon submission and before peer-review. There can be important differences between the submitted version and the official published version of record.

People interested in the research are advised to contact the author for the final version of the publication, or visit the DOI to the publisher's website.

- The final author version and the galley proof are versions of the publication after peer review.

- The final published version features the final layout of the paper including the volume, issue and page numbers.

Link to publication

\footnotetext{
General rights rights.

- You may freely distribute the URL identifying the publication in the public portal. please follow below link for the End User Agreement:

www.umlib.nl/taverne-license

Take down policy

If you believe that this document breaches copyright please contact us at:

repository@maastrichtuniversity.nl

providing details and we will investigate your claim.
}

Copyright and moral rights for the publications made accessible in the public portal are retained by the authors and/or other copyright owners and it is a condition of accessing publications that users recognise and abide by the legal requirements associated with these

- Users may download and print one copy of any publication from the public portal for the purpose of private study or research.

- You may not further distribute the material or use it for any profit-making activity or commercial gain

If the publication is distributed under the terms of Article $25 \mathrm{fa}$ of the Dutch Copyright Act, indicated by the "Taverne" license above, 


\title{
KOFFIE, KOOL \\ EN DE MOGELIJKHEDEN VAN \\ VOEDINGSVOORLICHTING
}

\author{
REDE \\ in verkorte vorm uitgesproken bij de aanvaarding \\ van het ambt van bijzonder hoogleraar voedingsgedrag \\ met de nadruk op voedingsvoorlichting \\ aan de Faculteit der Gezondheidswetenschappen \\ van de Universiteit Maastricht \\ op vrijdag 8 september 2000 \\ door \\ dr. ir. Johannes Brug
}


(C) 2000, J.Brug

ISBN 90-5681-082-0

De leerstoel is ingesteld door het Voedingscentrum en de Nederlandse Vereniging voor Preventie en GVO

Druk en printwerk: Unigraphic, Maastricht

Opmaak binnenwerk: NORA OOSTING [grafische vormgeving] 
Mijnheer de Rector, beste collega's, familie en vrienden;

\section{DE SMAAK VAN KOFFIE EN KOOL}

Per persoon drinkt u gemiddeld ongeveer 154 liter koffie per jaar. Ik drink zelf geen koffie, dus er moeten onder u zeker mensen zijn die nog meer dan 154 liter drinken. Ik lust geen koffie en ik kan u verzekeren: dat is een lastige afwijking in Nederland. Zowel privé als zakelijk is het drinken, aanbieden en accepteren van koffie een veel gebruikt smeermiddel. Toch is een afkeer van koffie heel natuurlijk. Ik durf te beweren dat iedereen hier in de zaal ooit niet van koffie hield.

Kool is in Nederland een van de meest gegeten groente. We eten in Nederland vooral bloemkool, maar ook spruitjes, broccoli, groene kool, rode kool, witte kool, spitskool en Chinese kool. We eten volgens de laatste Voedselconsumptiepeiling per persoon ruim 10 kilo kool per persoon per jaar. Ik hou zelf met name van spruitjes. Maar deze kooltjes zou ik eigenlijk ook niet lekker moeten vinden en ik heb het in ieder geval ooit niet lekker gevonden. Wij mensen houden namelijk van nature niet van bitter. Toch drinkt bijna iedereen koffie, en velen in de meest bittere variant, zwart zonder suiker, en velen van ons gaan uiteindelijk zelfs spruitjes waarderen.

Voedingsvoorlichters hebben het imago dat zij mensen willen laten eten wat wel gezond maar niet zo lekker is. En omdat met name smaak zou bepalen wat men eet, is voedingsvoorlichting gedoemd te mislulkken. Koffie en kool zijn echter voorbeelden van voedingsmiddelen die wij eigenlijk niet zouden moeten lusten, maar die wij wel met veel plezier dagelijks eten en ctrinken. Dit moet de voedingsvoorlichter hoop geven.

Smaakvoorkeuren zijn een heel belangrijke determinant van voedselkeuze. En smaakwoorkeuren kunnen de voedingsvoorlichter soms danig in de weg

\footnotetext{
' Met dank aan dr. Karin Hulshof, TNO Voeding, woor deze informatie.
} 
zitten. In haar zeer lezenswaardige boek Why Americans love, hate and fear foods citeert Michelle Stacey [1994] Wilbur Olin Arwater, de voedingsgoeroe tijdens het fin de siècle van de negentiende eeuw. Hij zei toen al: "If Americans could only shake the matter of taste, they would be far better off. Appetite would be a better guide, if it were not for the demands of the palate". Maar het feit dat we koffie kunnen leren drinken en kool kunnen leren waarderen, illustreert dat smaakvoorkeuren grotendeels zijn aangeleerd en niet aangeboren. Als we alleen zouden eten wat we 'van nature' lekker vinden, zouden we niet verder komen dan zoetigheid. Daarnaast is smaak zeker niet de enige bepalende factor voor voedselkeuze.

\section{VOEDINGSVOORLICHTING ALS WETENSCHAP}

Ilk mag $\mathrm{u}$ hier vandaag toespreken omdat ik de komende jaren de leerstoel Voedingsgedrag, met een nadruk op de voedingsvoorlichting mag bezetten. I $\mathrm{k}$ hoop dat mijn rede vandaag helpt om $u$ ervan te overtuigen dat voedingsvoorlichting niet die softe kant van de voedingsdiscipline is waar eigenlijk iedereen verstand van heeft. Met voedingsvoorlichting proberen we meestal uiteindelijk voedingsgedrag te beïnvloeden. Daar worden publieke middelen aan besteed. Een dergelijke ingreep waar publieke middelen aan worden besteed, is alleen te verantwoorden als er voldoende aanleiding voor is en als verwacht mag worden dat het gestelde doel wordt bereikt. Voedingsvoorlichting moet dus 'evidence based' zijn en daarvoor is een 'harde' wetenschappelijke benadering noodzakelijk. In voedingsnederland moet iedere uitspraak over voedingsepidemiologie of klinische voeding worden onderbouwd met ten minste een tiental referenties naar artikelen in wetenschappelijke tijdschriften. En zo hoort het ook. Zodra de implicaties voor voedingsvoorlichting besproken gaan worden, is het echter geoorloofd te praten over wat men denkt of voelt, zonder daarbij terug te vallen op enig empirisch fundament. Het feit dat het Voedingscentrum en de Nederlandse Vereniging voor Preventie en GVO deze leerstoel hebben ingesteld, illustreert gelulkkig dat het belang van een wetenschappelijke benadering van voedingsvoorlichting steeds breder wordt erkend. Ik wil het de komende drie kwartier dan ook 
hebben over de mogelijkheden van plammatige voedingsvoorlichting en wel met name ten behoeve van primaire preventie van voedingsgerelateerde aandoeningen.

\section{PlanMATIGE VOORLICHTING}

Wie aan planmatige voorlichting denkt, denkt aan Gerjo Kok, de peetvader van planmatige GVO in Nederland. Kok heeft een model voor planmatige voorlichting in Nederland geïntroduceerd [Brug, Schaalma, Kok, Meertens \& Van der Molen, 2000; Kok, Schaalma, De Vries, Parcel \& Paulussen, 1996]. Ik kan het natuurlijk niet laten om dat model vandaag ook weer te tonen (Figuur 1). Een aantal van u denkt wellicht "dit plaatje ken ik nu wel". Ik denk echter dat de meeste mensen in voedingsnederland inderdaad het plaatje kennen, maar dat de essentie en de implicaties van het model vaak nog niet goed begrepen worden en dat daarom het model zelden echt goed wordt toegepast.

\begin{tabular}{|c|c|c|c|c|}
\hline & & PLANNING & & \\
\hline $\begin{array}{c}\text { analyse van het } \\
\text { gezondheids- } \\
\text { probleem }\end{array}$ & $\begin{array}{l}\text { analyse van } \\
\text { risicogedrag } \\
\text { en -omgeving }\end{array}$ & $\begin{array}{c}\text { determinanten- } \\
\text { analyse }\end{array}$ & $\begin{array}{l}\text { interventie } \\
\text { ontwikkeling }\end{array}$ & $\begin{array}{l}\text { Implementatile } \\
\text { en diffusie van } \\
\text { de interventie }\end{array}$ \\
\hline & & EVALUATIE & & \\
\hline
\end{tabular}

Figuur 1: Het nodel woor planmatige gezondheldswoorlichting

Het model is eigenlijk een vereenvoudigde weergave van het Precede/ Proceed-model van Lawrence Green [Green \& Kreuter, 1999]. Green is, zoals de meesten van u zullen weten, voor planmatige GVO de internationale peetvader. Zijn model zegt kortweg dat wanneer 'we iets aan voorlichting willen gaan doen', we niet zomaar een aardige folder of tv-spot moeten gaan maken 
op basis van ervaring en creativiteit alleen, maar dat GVO, en dus ook voedingsvoorlichting, het resultaat moet zijn van een stapsgewijs proces van analyse, ontwikkeling, implementatie en evaluatie. Het uitgangspunt voor iedere voedingsvoorlichtingsinterventie moet een gezondheidsprobleem zijn dat ernstig en omvangrijk genoeg is om er geld en andere middelen aan te besteden. Vervolgens moet dat probleem in ieder geval voor een relevant deel worden veroorzaakt door voedingsgedrag. De volgende stap in het model is het zo precies mogelijk analyseren waarom bepaalde groepen mensen er gezondheidsbedreigende voedingsgewoonten en geen gezondheidsbevorderende voedingsgewoonten op na houden. Op basis van die gedragsdeterminantenanalyse kunnen de juiste interventiedoelen worden geformuleerd, en de interventiemethodieken en -techmieken worden gekozen of ontwilkkeld om tot concrete interventieactiviteiten te komen die het mogelijk maken die doelen te bereiken. Tot slot moeten die activiteiten zo worden geïmplementeerd dat de doelgroep zo goed mogelijk wordt bereikt.

Ik presenteer dit model niet alleen om mijn leermeesters te paaien. Het model doet dienst om mijn verhaal vandaag enige structuur te geven. Ik zal in het vervolg van mijn rede eerst kort ingaan op enkele voedingsgerelateerde gezondheidsproblemen met de bijbehorende voedingsoorzaken die het uitgangspunt van voedingsvoorlichting zijn. Vervolgens zal ik uitgebreider ingaan op waarom mensen niet altijd even gezond eten en wat de mogelijkheden van voorlichtingsinterventies zijn om daar wat aan te veranderen. Het zwaartepunt van mijn redle zal dus gaan over de determinanten van voedingsgedrag en de mogelijkheden van voedingsvoorlichting. Ik zal bij deze beide onderwerpen kort het huidige wetenschappelijke inzicht schetsen, ik zal -waar dat gepast is- aangeven wat wij, de onderzoeksgroep waar mijn leerstoel is ondergebracht, aan dat inzicht hebben bijgedragen. Ook zal ik ingaan op de plannen die wij hebben voor de komende jaren om enikele van de vele leemtes in onze kennis en inzichten over determinanten van voedingsgedrag en werkzame voedingsvoorlichtingsinterventies weg te werken. In de loop van mijn verhaal zal hopelijk duidelijk worden dat voedingsvoorlichting in Nederland steeds meer gebaseerd is op een degelijke gedragsanallyse, en gelukkig steeds vaker op een min of meer gedegen gedragsdeterminantenanalyse. De vertaling van deze analyseresultaten in interventieactiviteiten en campagnes wordt echter nog grotendeels gedaan op basis van 'leuke ideetjes' en 'maar eens wat anders doen' en veel te weinig op basis van een systema- 
tische analyse van bestaande empirische gegevens over effectieve voorlichtingsmethodieken en -technieken of op basis van gerandomiseerd, gecontroleerd vooronderzoek naar die methoden en technieken.

\section{GEZONDHEIDSPROBLEMEN EN VOEDINGSGEDRAG}

Het onderzoek naar de relatie tussen voeding en gezondheid is niet het werkterrein van de voedingsvoorlichter en hoort niet tot mijn leeropdracht. De voorlichter maakt echter wel dankbaar gebruik van de resultaten van dit onderzoek, want inzichten over welke voedingsgewoonten mede oorzaak zijn van bepaalde aandoeningen, moet het uitgangspunt zijn voor de planning en ontwikkeling van voedingsvoorlichtingsinterventies. Alleen wanneer voeding van relevante invloed is op het vóórkomen of op het voorkómen van een gezondheidsprobleem, en alleen als dat gezondheidsprobleem omvangrijk en ernstig genoeg is, is er aanleiding om voedingsvoorlichtingsinterventies te overwegen.

Wat we eten is zeker van invloed op onze gezondheid [Willett, 1994]. Wie niet of echt te weinig eet, raakt ondervoed en gaat uiteindelijk dood. Daarnaast weten we allemaal dat het belangrijk is dat wat je eet een aantal essentiële voedingsstoffen bevat. In Nederland is voldoende voedsel. Ondervoeding op grote schaal zagen we in ons land voor het laatst in de hongerwinter van 1944-1945. Sindsdien komt ondervoeding nauwelijks nog voor, behalve in extreme gevallen zoals bijvoorbeeld bij patiënten met anorexia nervosa, mensen met bepaalde vormen van kanker en bij bepaalde groepen ouderen.

In de loop van de vorige eeuw is in de westerse wereld het perspectief in het onderzoek naar voeding en gezondheid, en daarmee ook in de voedingsvoorlichting, verschoven van aandacht voor de gevolgen van tekorten naar de gevolgen van overdaad. Overvoeding werd in de tweede helft van de twintigste eeuw in de westerse wereld steeds meer als de belangrijkste voedingsgerelateerde determinant van ongezondheid gezien: te veel calorieën, te veel verzadigd vet, te veel zout. En overvoeding is nog steeds een belangrijk thema in voedingsvoorlichting, aangezien de consumptie van verzadigd vet nog 
steeds te hoog is [Zo eet Nederland, 1998], en de prevalentie van overgewicht in Nederland stijgt [Seidell, 1997].

De laatste jaren is er weer meer aandacht voor tekorten in de voeding van inwoners van rijke landen zoals de onze. Niet omdat in deze landen het gevaar voor echte ondervoeding weer op de loer zou liggen, maar omdat er steeds meer aanwijzingen zijn dat de consumptie van bepaalde categorieën voedingsmiddelen en de inneming van bepaalde micronutriënten voor veel mensen sub-optimaal zou zijn vanuit het oogpunt van de bevordering van een optimale gezondheid ['positive health"; zie Kok, Schaalma \& Brug, 2000] en het helpen voorkomen van bepaalde chronische aandoeningen op latere leeftijd.

Uit epidemiologisch onderzoek blijkt bijvoorbeeld dat groente- en fruitconsumptie een invers verband laat zien met het risico op verschillende vormen van kanker: hoe meer groente en fruit wordt gegeten, hoe lager het risico. Dat lagere risico kan (nog) niet worden toegeschreven aan bepaalde specifieke nutriënten of andere, zogenaamde niet-nutritieve, stoffen in groente en fruit [Block, Patterson \& Subar, 1992]. Daarom is compensatie door voedingssupplementen nog geen alternatief. De consumptie van groente en fruit in Nederland is echter zeker niet optimaal en is tussen 1988 en 1998 zelfs gedaald, voor sommige groepen zelfs met 40 procent [Zo Eet Nederland, $1998]^{2}$.

Voedingsvoorlichting aan het algemene publiek in het kader van de bevordering van gezondheid en primaire preventie van veelvoorkomende chronische aandoeningen richt zich daarom tegenwoordig met name op het terugdringen van de consumptie van te veel calorieën en te veel verzadigd vet, en op het stimuleren van de groente- en fruitconsumptie. De landelijke voedingscampagnes die gecoördineerd worden vanuit het Voedingscentrum, zijn hiervoor illustratief. Van 1992 tot 1994 waren dit de zogenaamde Let-op-Vet campagnes. Maar daarna zijn die, onder de titel 'Goede Voeding, Wat Let Je?', breder van opzet geworden, met een steeds belangrijkere plaats voor de pro-

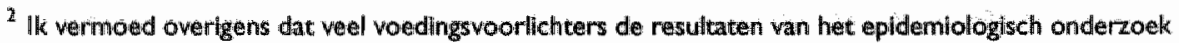
naaf de te lage groente- en fruitconsumptie haast met vreugde heblben ontwangen omdat hen dit de kans bood om eindelijk weer eens de vrolijke boodschap wain 'eet meer' te kunnen verkondigen. Dit na jarenlang steeds matar wijzen op de merites van matigheid in de campagnes gericht op vetreductie.
} 
motie van groente en fruit. In de toekomst zal de aandacht woor promotie van het eten van meer van bepaalde voedingsmiddelen waarschijnlijk verder toenemen. De pogingen tot het ontwikkelen van 'functional foods' met een specifieke gezondheidsbevorderende of zelfs ziektebestrijdende werking zullen daartoe aanleiding geven. Recent is in het kader van de gelijkschakeling van wetgeving binnen de landen van de Europese gemeenschap meer ruimte gekomen voor het verrijken van voedingsmiddellen in Nederland. Ook zijn er verschillende voedingsmiddelen geïntroduceerd met impliciete en soms expliciete claims voor een specifieke gezondheidsbevorderende werking, zoals yoghurtdranken met voedingsvezel of een vermeend serumcholesterolverlagend effect, en margarine met plantensterolen. De verwachting is dat er de komende jaren nieuwe voedingsmiddelen met verdergaande gezondheidsbevorderende claims en/of werking op de markt zullen komen. Daarnaast zijn er steeds meer voedingsmiddelen met macronutriëntsubstituten die wat betreft smaak niet of nauwelijks verschillen van de producten met de originele ingrediënten, maar wel minder calorieën en/of verzadigd vet bevatten. De bekendste en meest voorkomende zijn suikervervangers in frisdrank, en de meeste van $u$ zullen ook op de hoogte zijin van de al weer een beetje verstomde discussie rond de vetvervanger onder de merknaam Olestra. De werkelijke potentie van veel van dit soort producten voor gezondheidsbevordering moet nog duidelijk worden. Producten die deze toets kunnen doorstaan, zullen wellicht opgenomen kunnen worden in doelstellingen voor voedingsvoorlichting ${ }^{3}$. Tot die tijd zal ons onderzoek bij de capaciteitsgroep GVO met name gericht zijn op onderzoek ten behoeve van interventies voor het terugdringen van de consumptie van verzadigd vet en energie en het stimuleren van de groente en fruitconsumptie.

Om met GVO-interventies een lagere vet-en energieconsumptie en een hogere groente- en fruitconsumptie te kunnen bereiken, dus om bepalde voedingsgewoonten te kunnen beinvloeden, moeten we inzicht hebben in waarom mensen eten wat ze eten. We praten dan over de determinanten van voe-

\footnotetext{
${ }^{3}$ Er zijn natuurlikk al enkele woorbeelden van dit soort producten die binnen voedingswoorlichtimg al van harte worden aanbevolen. Denk hierbil bijvoorbeeld an halvarines, dieetrnargarines en whalvarlines. Ook halfvolle melkproducten zouden als gezondheidsbeschenmend voedsel kunnen worden beschouwd.
} 
dingsgedrag*. De studie naar deze gedragsdeterminanten is dan ook een belangrijke tak van onderzoek bij de capaciteitsgroep GVO en zal een belangrijk onderdeel zijn van het onderzoek dat ik in het kader van mijn leerstoel hoop te initiëren en uit te voeren.

\section{DETERMINANTEN VAN VOEDINGSGEDRAG}

\section{INLEIDING}

Waarom eten we? Deze vraag is in essentie al beantwoord. Als we niet eten, gaan we dood. Maar er is nog wel iets meer over te zeggen. De rol van eten in het vervullen van menselijke behoeften is niet altijd dezelfde geweest. Leslie Gofton [Gofton, 1996] heeft een heel aardig historisch overzicht gemaakt van verschillende motieven om te eten die zij kernachtig samenvat. In het zogenaamde pre-industriële tijdperk aten wij volgens Gofton om te leven ('eat to live'). Voedsel was een schaars goed en voor veel mensen was het een strijd voldoende eten bij elkaar te scharrelen om in leven te blijven. In het daaropvolgende industriële tijdperk aten wij volgens Gofton om te werken. Het was zaak voldoende eten te bemachtigen om in staat te zijn de vaak zware lichamelijke belasting van het werk vol te houden'. In wat Gofton het postindustriële tijdperk noemt, zou 'eat for health' het motief om te eten zijn. Wij zouden dus eten om onze gezondheid te optimaliseren. De lage groente- en fruitconsumptie en de overgewichtepidemie falsificeren mijns inziens Goftons idee. Een socioloog als Grivetti zegt dan ook: "Most humans

\footnotetext{
${ }^{4}$ In kringer van wetensehappers die zich met name richten op het onderzoek naar dile iriwloed van voeding op gezondheld, op warom mensen gezond of ongezond eten en op manieren om mensen ertoe aan te zetten om gezonder te gaan eten, wordt waak de term voedingsgedrag gebruikt in navolging wan de Engelstallige termen als dietary behaviour en nutritional behaviour.
}

${ }_{5}^{5}$ Men zou ook kunnen zeggen dat men at on voldoende te kunnen bewegen. Tegenwoordig gaan mensen bewegen om te kwnnen eten. 
do not select foods for their nutritional value. Those who do are community nutritionists, dieticians, nutrition scientists et cetera and their professional clients" [Grivettit, 1997].

Ik denk dat Gofton het pre-industriële en het industriële tijdperk goed karakteriseert, maar als gezondheidsbevordering de belangrijkste determinant van voedselkeuze is in het post-industriële tijdperk, dan hebben wij dat stadium nog niet bereikt. Grivetti is daarentegen wel weer erg pessimistisch, want onderzoek wijst uit dat gezondheidsbevordering of -bescherming wel degelijk een belangrijk motief voor voedselkeuze kan zijn. Ik kom hier later op terug.

\section{WAAROM ETEN WIJ WAT WE ETEN?}

Een volgende vraag is: waarom eten we wat we eten? Wat drijft onze voedselkeuze? Op basis van de huidige inzichten wordt voedselkeuzegedrag door een combinatie van biologische, psychologische, sociale en culturele factoren beïnvloed.

Laat ik een voorbeeld geven. Waarom eten wij in Limburg zo graag vlaai? De bioloog kan naar voren brengen dat mensen een aangeboren voorkeur voor zoet hebben. Hij/zij zou ook kunnen opperen dat vlaai een hoge energiedichtheid heeft en dat mensen een aangeboren eigenschap hebben om energiedichte voeding makkelijk te leren waarderen. De evolutiepsycholoog zou deze eigenschap mogelijk verklaren uit het feit dat de menselijke soort is geëvolueerd in tijden dat voedselschaarste veel waarschijnlijker was dan overvloed en dat de eigenschap om vooral energierijk voedsel te leren waarderen, past in de 'survival of the fittest'-theorie [Birch, 1999]. De leerpsycholoog kan aangeven dat vruchtenvlaai al op jonge leeftijd frequent aan kinderen wordt aangeboden en dat vlaai lijkt op ander voedsel waar we al aan gewend waren voordat we in aanraking kwamen met vlaai, zoals viuchtenhapjes woor peuters, appelmoes, brood met jam. Vanuit leerpsychologisch en sociaal-psychologisch perspectief zou verder kunnen worden opgemerkt dat we geacht worden om dit soort voedsel te nuttigen bij veel sociale gelegenheden, zoals verjaardagen, feestdagen, geboortes, trouwerijen, promoties en oraties en dat wij derhalve vlaai met viering en feest zijn gaan associëren en daarom zijn gaan waarderen [Rozin, 1996]. Daarbij komt dan nog eens dat we anderen, 
waaronder onze ouders, vrienden en collega's, deze voedingsmiddelen zien eten en hun daar plezier aan zien beleven. Bij sociale gelegenheden merken we verder dat andere mensen van ons verwachten, en ons zelfs onder druk zetten, dat we een stukje vlaai nemen, en dat het onbeleefd is om het af te slaan. Dat er hier bij ons veel vlaai wordt gegeten, zou ook verklaard kunnen worden door het feit dat vlaai in Limburg overal, altijd en relatief goedkoop te krijgen is. Vlaai kan je zo eten, zonder bereidingstijd en vrijwel zonder gereedschap. Vruchtenvlaai is verder zeker geen ongezonde keuze binnen de voedingsmiddelengroep van koek en gebak, en aan een normale vlaaiconsumptie zijn geen risico's verbonden. Tot slot kan het eten van vlaai een onbewuste gewoonte zijn geworden doordat wij steeds vlaai bij allerlei gelegenheden te eten krijgen.

Ongemerkt zijn hiermee de belangrijkste theoretische concepten de revue gepasseerd waarmee we voedingsgedrag proberen te verklaren: genetische factoren, blootstelling en conditionering waardoor gewoonten ontstaan, verschillende sociale invloeden, eigen-effectiviteitsverwachtingen en vaardigheden, attitude of uitkomstverwachtingen, risicopercepties en gezondheidsoverwegingen, en omgevingsfactoren. De leeropdracht richt zich op determinanten van voedingsgedrag met speciale aandacht voor voedingsvoorlichting. Ons onderzoek naar determinanten van voedingsgedrag zal daarom met name tot doel hebben om aangrijpingspunten voor planmatige voedingsvoorlichting te identificeren [Brug et al., 2000]. Ik ben daarom geïnteresseerd in belangrijke en veranderbare determinanten. Inzicht in veranderbare determinanten van gedrag komt vooral voort uit de psychologie en de health promotion literatuur.

\section{PSYCHOLOGISCHE DETERMINANTEN ALS BASIS VOOR VOEDINGSVOORLICHTING}

Psychologische determinanten zijn verreweg de belangrijkste basis voor reclame voor voedsel en voor voedingsvoorlichting. Het onderzoek naar psychologische determinanten van voedselkeuze baseert zich vooral op leertheorieën en sociaal-psychologische theorieën. Het onderzoek op basis van leertheorieën richt zich met name op hoe en waarom kinderen bepaalde voedselvoorkeuren aanleren. Principes uit die leertheorieën worden ook veel toege- 
past in commerciële reclames voor voedingsmiddelen, maar slechts in zeer beperkte mate in voedingsvoorlichting. Inzichten uit de sociale psychologie zijn de basis voor de belangrijkste voedingsvoorlichtingscampagnes in het afgelopen decennium. Ik zal eerst de verschillende psychologische determinanten van voedselkeuze op een rij zetten. Daarna ga ik in op omgevingsdeterminanten van voedselkeuze.

\section{Wat de boer niet kent dat eet hij niet}

Het spreekwoord zegt dat wat de boer niet kent, hij niet eet. Andersom geldt ook dat de boer wel eet wat hij heeft leren kennen. Hetzelfde geldt natuurlijk voor de boerin. Mensen lijken in het algemeen een aangeboren wantrouwen tegen nieuw, onbekend voedsel te hebben. Dit wantrouwen wordt vanuit de evolutiepsychologie verklaard met de veronderstelling dat de kans op overleven groter was, en wellicht is, als je niet zomaar alles als eetbaar beschouwt [Birch \& Fisher, 1996].

Blootstelling aan nieuwe voedingsmiddelen is anderzijds wellicht de belangrijkste determinant van voedselkeuze. Mensen leren datgene te eten waaraan zij worden blootgesteld. Herhaalde blootstelling aan bepaald voedsel leidt tot hogere waardering voor dat voedsel, zelfs als dat voedsel in eerste instantie niet op veel waardering kan rekenen [Birch, 1999]. . Het onderzoek waaruit dit blijkt, is echter vooral uitgevoerd bij proefdieren en jonge kinderen. Als blootstelling een belangrijke determinant van voedselvoorkeuren is, maar we anderzijds geneigd zijn om nieuw voedsel te wantrouwen, hoe leren we dan eten?

Ten eerste is het wantrouwen tegen onbekend voedsel zeker niet absoluut. In tijden van schaarste is het natuurlijk raadzaam om niet al het onbekende voedsel af te wijzen. Ook variëren mensen in de mate van wantrouwen. Mensen die extreem wantrouwend staan tegenover onbekend voedsel, worden wel 'food-neophobes' genoemd [Pliner \& Hobden, 1992]. Voor mensen die juist graag experimenteren met nieuwe voedingsmiddelen, is de term 'food-neophile' geïntroduceerd. In de tweede plaats lijkt voedselneofobie in de vroege kinderjaren minder sterk te zijn en kunnen kinderen al in een heel vroeg stadium wennen aan verschillende smaken. Er zijn aanwijzingen dat de ontwikkeling van voedselvoorkeuren wellicht al voor de geboorte en in ieder geval direct daarna begint. Zo hebben jonge ratten van moeders die tijdens 
de zwangerschap regelmatig knoflook eten, na de geboorte ook een sterkere voorkeur voor knoflook [Hepper, 1988]. Kinderen die borstvoeding krijgen worden vaker 'makkelijke eters' wat verklaard wordt uit het feit dat borstvoeding, afhankelijk van wat de moeder allemaal eet, veel meer in smaak varieert dan flesvoeding met een standaardsamenstelling en -smaak [Mennella \& Beauchamp, 1996].

Daarnaast zijn er een viertal manieren waarop we mensen kunnen verleiden zich bloot te stellen aan nieuwe smaken en producten: observational learning of model-leren, smaak-smaak leren, smaak-omgeving leren en smaak-nutriënt leren [Birch, 1999; Birch \& Fisher, 1996]. Als u andere mensen lets ziet eten dat u niet kent, en $u$ ziet ook dat dat eten die anderen plezier, genot en gezondheid verschaft, zult u eerder geneigd zijn om dat onbekende voedsel ook eens te proberen. Dit model-leren of observationeel leren van voedselvoorkeuren gebeurt grotendeels onbewust. Voor kinderen is dit een belangrijke manier om nieuwe dingen te leren eten. De mogelijkheden van model-leren in voedingsvoorlichting voor jongeren of volwassenen zijn echter nog nooit systematisch onderzocht. Collega Anke Oenema zal in het kader van haar promotieonderzoek hier de komende jaren meer zicht op proberen te krijgen. Een tweede manier om mensen een nieuw product met een onbekende smaak te leren waarderen, is het nieuwe product direct aan een smaak te koppelen waar al een voorkeur voor bestaat. Dit wordt smaaksmaak leren genoemd. Nadat we een aantal keren aan de nieuwe smaak in combinatie met een bekende aantrekkelijke smaak zijn blootgesteld, ontwikkelen we langzamerhand ook een grotere voorkeur voor de onbekende smaak [Birch, 1999]. Veel ouders weten deze methode feilloos toe te passen door voor de kinderen groente met appelmoes te mengen. Een derde manier om mensen te verleiden tot iets nieuws, is de omgeving waarin mensen aan dit voedsel worden blootgesteld zo aantrekkelijk mogelijk te maken. De kans dat je iets lekker gaat vinden dat je voor het eerst een paar keer tijdens een prachtige vakantie op een tropisch eiland hebt gegeten, is groter dan dat je iets gaat waarderen waaraan je bijvoorbeeld tijdens een verblijf aan het ziekenhuis werd blootgesteld. Tot slot leren mensen makkelijker nieuw voedsel te waarderen met een hoge energiedichtheid [Birch, 1999]. Onderzoek toont aan dat we makkelijker een voorkeur voor voèdsel met veel calorieën aanleren dan voor voedsel dat hetzelfde van smaak is, maar een lagere energiewaarde heeft. Zoals ik eerder opmerkte, worden inzichten over het aanleren van voedsel- 
voorkeuren nog nauwelijks toegepast in promotie van gezonde voeding. Daar moet de komende jaren verandering in gaan komen. Recent is in samenwerking met Kees de Graaf van Wageningen Universiteit en Annette Stafleu van TNO-Voeding en met hulp van Unilever en het Groente- en Fruitbureau een onderzoeksprogrammavoorstel opgesteld om GVO-toepassingen van determinanten van blootstelling en smaakvoorkeuren in kaart te brengen. In samenwerking met Unilever heeft collega Ingrid Steenhuis samen met stagiaire Floortje Molenaar, in dit kader een voorstudie gedaan [Steenhuis, Molenaar, Van Assema, Brug \& Mela, in voorbereiding].

\section{Verwachtingen en overwegingen}

Zoals ik al eerder opmerkte, steunt het onderzoek naar determinanten van voedingsgedrag dat ten grondslag ligt aan voedingsvoorlichtingsinterventies, vooral op de sociale psychologie. Onderzoek binnen deze discipline heeft geleid tot een aantal gedragsverklaringstheorieën en gedragsveranderingstheorieën. De meeste van deze theorieën zijn zogenaamde expectancy value of in ieder geval 'belief-gebaseerde' modellen. In Europa is met name de theorie van planmatig gedrag [Ajzen, 1991] veelvuldig gebruikt als basis voor onderzoek naar determinanten van voedingsgedrag en voedingsvoorlichtingsinterventies [Godin \& Kok, 1996; Stafleu, De Graaf, Van Staveren \& De Jong, 1991]. In Nederland bestaat een variant van deze theorie, het zogenaamde ASE-model. De basis hiervoor is gelegd door Hein de Viries en Gerjo Kok IDe Vries, Dijkstra \& Kuhlman, 1988; Kok, De Vries, Mudde \& Strecher, 1991], en het model is onder andere gebruikt voor de ontwikkeling van de Let-opVet campagnes [Van Wechem, Brug, Van Assema, Kistemaker, Riedstra \& Löwik, 1998]. In de Verenigde Staten zijn de sociale leertheorie en de daarop voortbouwende sociaal-cognitieve theorie [Bandura, 1986] populair als basis voor voedingsvoorlichtingsonderzoek. Een derde theorie die regelmatig gebruikt is in onderzoek naar determinanten van voedingsgedrag, is het health belief model [bijv. Campbell, DeVellis, Strecher, Ammerman, DeVellis \& Sandler, 1994]. In al deze modellen worden verwachtingen of overwegingen, vaak aangeduid met de Engelstalige term 'beliefs', verondersteld een belangrijke determinant van gedrag te zijn.

Op basis van Koks pleidooi voor 'problem driven' sociaal-psychologisch onderzoek [Kok et al., 1996], het vertalen van verschillende theorieën naar 
de praktijk van voedingsvoorlichting door Karen Glanz [Glanz \& Rudd, 1993], de opkomst van aansprekende en praktisch toepasbare theoretische raamwerken als Stages of Change [Prochaska, DiClemente $\&$ Norcross, 1992] en meer recent de ontwikkeling van het Intervention Mapping-protocol [Bartholomew, Parcel, Kok \& Gottlieb, 2000], vindt steeds meer probleemgestuurd onderzoek plaats waarbij inzichten uit verschillende theoretische raamwerken worden geỉntegreerd.

Welke verwachtingen, overwegingen of beliefs spelen nu een rol in het bepalen van wat iemand eet en drinkt? Ik zal deze vraag proberen te beantwoorden aan de hand van de resultaten van het onderzoek naar beliefs ten aanzien van vetconsumptie. Af en toe zal ik ook putten uit de resultaten van het onderzoek naar de determinanten van groente- en fruitconsumptie.

Op basis van probleemgestuurd determinantenonderzoek zijn globaal vier soorten overwegingen als verklaring van vetconsumptieniveau geïdentifceerd: risicopercepties en andere gezondheidsoverwegingen, een afweging van (overige) voor- en nadelen waaronder smaakoverwegingen, een inschatting van de eigen mogelijkheden en vaardigheden om meer of minder vet te eten, en een inschatting van wat de sociale omgeving verwacht en doet met betrekking tot vetconsumptie.

\section{Gezondheidsoverwegingen en risicopercepties}

Eerder in mijn verhaal zei ik $\mathrm{u}$ dat gezondheidsbevordering voor de meeste mensen waarschijnlijk niet de belangrijkste motivatie voor voedselkeuze is. Maar gezondheid is, onder bepaalde voorwaarden, wel een van de relevante determinanten van voedselkeuze. Zo hebben wij zeker de neiging om voedsel waarvan wij denken dat wij er ziek van worden, te vermijden. We moeten er dan wel snel ziek van worden en niet pas jaren later en met een relatief kleine kans, zoals bij de relatie tussen bijvoorbeeld de consumptie van verzadigd vet en hart- en waatziekten. Laat ik een voorbeeld geven om dit te illustreren.

Iemand die na het eten wan mosselen de aansluitende nacht grotendeels op het toilet doorbrengt, zal vaak al na één, maar in ieder geval na enkele van soortgelijke ervaringen het eten van mosselen vermijden. Het betreft hier een eenvoudig proces van operant conditioneren. Maar iemand krijgt in de regel na het eten van ganzenlever, gevolgd door een varkenshaasje met champignonroomsaus, en afgesloten met een ruime portie ijs met slagroom, niet 
acuut hartklachten. Deze persoon heeft waarschijnlijk wel na de maaltijd een aangenaam gevoel van verzadiging. Ook hier vindt een eenvoudig leerproces plaats, maar in dit geval leidt dat niet tot afkeer van varkenshaas en roomijs, maar tot bekrachtiging. Deze persoon voelt de aangename gevolgen van een copieuze maaltijd aan den lijve. Van de mogelijke negatieve gevolgen voor datzelfde lijf op de lange termijn als gevolg van te vaak copieus dineren, merkt hij of zij zo vlak na die maaltijd niets. Deze persoon zal best geleerd kunnen worden dat te veel varkenshaas en roomijs zijn of haar risico op harten vaatziekten op de langere termijn zal verhogen en dat het daarom verstandig is om niet te vaak zwaar te tafelen. Een dergelijk leerproces gaat echter verder dan een eenvoudig conditioneringsprincipe. Het gaat dan om een proces van wat we intelligent leren kunnen noemen. Gedrag dat door conditionering is ontstaan en steeds weer wordt bekrachtigd, is moeilijk af te leren door intelligent leren. Met andere woorden: kortetermijnvoordelen van lekker eten bepalen onze voedselkeuze meestal in sterkere mate dan de nadelen op lange termijn. Het blijkt lastig te zijn mensen er werkelijk van te overtuigen dat iets waar je je goed door voelt, eigenlijk slecht voor je is. Lastig, maar niet onmogelijk. Onderzoek wijst uit dat Nederlanders, meestal na smaak, gezondheid als een van de belangrijkste overwegingen bij voedselkeuze noemen. Onderzoek van collega Matt Commers wijst verder uit dat Nederlanders voeding als een belangrijk middel tot gezondheidsbevordering erkennen. Belangrijke gezondheidsgedragverklarende modellen zoals het health belief model en de protectie motivatie theorie gaan er dan ook van uit dat risicoperceptie een belangrijke determinant van gezondheidsbeschermend gedrag is. Dat fabrikanten van voedingsmiddelen er ook van uitgaan dat gezondheidsoverwegingen een rol spelen bij voedselkeuze blijkt uit de wens om gezondheidsclaims op verpakkingen te plaatsen. Of, wanneer en onder welke voorwaarden deze claims tot verandering van voedingsgedrag kunnen leiden is nog onderwerp van onderzoek [Van Assema, Glanz, Brug \& Kok, 1996].

Onze kennis over hoe we informatie over risico's en gezondheidseffecten van voeding moeten communiceren, is echter nog beperkt. Er zijn wel aanwijzingen dat de wijze waarop informatie over risico's van bepaalde voedingsgewoonten wordt gepresenteerd, van invloed kan zijn op de mate waarin deze informatie mensen motiveert om anders te gaan eten. In samenwerking met collega Rob Ruiter van de Faculteit der Psychologie is een begin gemaakt met onderzoek naar effectiviteitverhogende kenmerken van voor- 
lichting over gezondheidsgevolgen van voedingsgewoonten. We zijn begonnen met oriênterend onderzoek naar 'message framing'. Een voorlichtingsboodschap waarin risico-informatic wordt gepresenteerd, kan positief of negatief worden 'geframed'. Een positief frame betekent dat de gezondheidswinst van preventief gedrag wordt gepresenteerd. Bij een negatief frame wordt het gezondheidsverlies van risicogedrag gecommuniceerd. 'Eet veel groente en je wordt heel gezond' is een boodschap in een positief frame. Bij 'als je geen groente eet, heb je meer kans op kanker', is sprake van een negatief frame. Er zijn aanwijzingen dat positief 'geframede' woorlichting in primaire preventie effectiever is dan boodschappen in een negatief frame. Of dit yoor voedingsvoorlichting ook opgaat, valt nog te bezien. De eerste data-analyses laten geen eenduidige resultaten zien. Voorlichting over gezondheidsrisico's wordt nog steeds vaak negatief geframed. In extreme mate is dit het geval bij angstaanjagende voorlichting. Volgens de eerder genoemde theotieèn wordt risicoperceptie bepaald door 'ernst' en 'kans'. Mensen hebben een hoge risicoperceptie met betrekking tot diabetes mellites type 2 als zij deze vorm van diabetes zowel een ernstige ziekte vinden en de kans dat zij zelf deze ziekte kunnen krijgen als redelijk hoog inschatten. Alleen dan zouden zij gemotiveerd kunnen worden tot beschermend gedrag. Van oudsher probeerden voorlichters de factor ernst vooral te manipuleren door in voorlichting angst voor de ziekte op te roepen. De afgelopen jaren hebben we dit nog gezien bij de vuurwerkcampagnes en met name in het buitenland ook in de HIV-preventiecampagnes. Angst voor een ziekte, zonder een besef van persoonlijke vatbaatheid en zonder vertrouwen dat je iets kan doen dat ook echt helpt om een ziekte te vermijden, leidt niet tot preventief gedrag en kan zelfs averechts werken [Ruiter, Kok \& Abraham, in voorbereiding]. In het kader van de toepassing van nieuwe technieken in de productie of conservering van voedsel is het overigens zo dat in de risicovoorlichting ook een perspectiefverschuiving gaat optreden. In plaats dat we consumenten van de risico's van bepaalde voedingsgewoonten willen overtuigen, zullen we in de toekomst waarschijnlij k steeds vaker juist onrealistisch hoge risicopercepties rond allerlei 'modern' voedsel willen nuanceren. De discussie over en de afkeer van grote groepen consumenten van voedsel met genetisch gemodificeerde ingrediënten is in dit kader zeer actueel. Risicocommunicatie rond 'nieuw' voedsel zal een belangrijk onderzoeksthema worden voor onze onderzoeksgroep. 


\section{Een afweging van andere voor-en nadelen}

Rationeel keuzegedrag veronderstelt een afweging van voor- en nadelen van de verschillende mogelijke keuzen. Onderzoek heeft aangetoond dat een dergelijke afweging inderdaad een rol speelt bij voedselkeuzegedrag. Smaak en hedonistische overwegingen zijn hier wellicht het belangrijkst "Birch, 1999; Glanz, Basil, Maibach, Goldberg \& Snyder, 1998; Keenan, AbuSabha, Sigmant-Grant, Achterberg \& Ruffing, 1999]. Westenhoefer en Pudel [1993] lieten zien dat eten erg hoog op ons lijstje van plezierbezorgende activiteiten staat. Alleen seks en feestelijke gelegenheden worden in dit kader belangrijker gevonden. Mensen eten wat ze lekker vinden en zullen voedingsmiddelen waarvan ze geen aangename smaak verwachten, vermijden. Nu zijn smaken, zoals ik in mijn inleiding al aangaf, vrijwel volledig aangeleerd [Capaldi, 1996] en daarmee in principe ook af te leren. Smaakvoorkeuren zijn echter wel de belangrijkste bottleneck in verandering van voedingsgedrag. Als mensen verwachten dat gezondere voeding niet lekker is, kan de voorlichter wel ophouden. De tweede Let-op-Vet campagne had dit goed begrepen. "Lekker met minder vet' was het motto, met de achterliggende gedachte dat de consument eerst moest worden overtuigd dat minder vet minstens net zo lekkker kan zijn, voordat een dergelijke gedragsverandering overwogen zal worden. Bepaalde smaken zijn helaas veel eenvoudiger aan te leren dan andere. We ontwikkelen bijwoorbeeld heel makkelijk een voorkeur voor smaken die gekoppeld zijn aan energiedichte voedingsmiddelen en veel moeilijiker voor energiearme voedingsmiddelen. Vet- en suikerrijke voedingsmiddelen ga je daarom snel lekker vinden. Naast smaakverwachtingen en verwachtingen over gezondheidseffecten, bepalen verwachtingen over kosten, bereidingsgemak en overeenkomsten met wat men gewend is te eten mede de attitude ten aanzien van gezonde voeding [Brug, Riedstra, Pruyn \& Aarnink, 1993; Glanz et al., 1998]. Met name uit ons onderzoek naar de determinanten van groente- en fruitconsumptie bleek dat 'convenience' belangrijk was [Brug, Debie, Van Assema \& Weijts, 1995; Brug, Lechner \& De Vries, 1995].

\section{Wat we denken dat we zelf (aan)kunnen}

De laatste tien à vijftien jaar is Bandura's [1986; 1999] sociaal-cognitieve theorie, en met name het concept eigen-effectiviteitsverwachtingen, erg populair in onderzoek naar determinanten van voedingsgedrag [Baranowski, Cullen \& Baranowski, 1999]. Eigen-effectiviteitsverwachtingen zijn de 
inschatting die iemand maakt of hij in staat is tot bepaald specifiek gedrag. Het ligt natuurlijk voor de hand dat iemand pas zal proberen om minder vet te gaan eten als hij enig vertrouwen heeft dat dat ook zal lukken en onderzoek bevestigt dat dan ook. Hoe voor de hand dit misschien mag lijken, in voedingsvoorlichtingscampagnes is hier tot voor kort nauwelijks rekening mee gehouden. Voedingsvoorlichting richtte zich vooral of alleen op kennisen attitudeverandering en wrijwel nooit op de vaardigheden om die nieuwe attitude om te zetten in anders eten.

\section{De invloed van andere mensen}

Verschillende sociale invloeden bepalen mede ons voedingsgedrag. Het blijkt echter moeilijk te zijn deze invloed van de sociale omgeving goed in kaart te brengen. In onderzoek naar determinanten van voedselkeuze bij volwassenen komt de sociale omgeving meestal als een relatief onbelangrijke determinant naar voren. Attitudes en inschattingen van de eigen-effectiviteit hebben meestal een sterkere correlatie met gedrag. Die attitudes zijn overigens zelf wel weer de resultante van onder andere sociale invloeden. Er is ook onderzoek waaruit op een meer indirecte manier duidelijk is geworden dat sociale invloeden weldegelijk een belangrijke rol spelen, bijwoorbeeld door de overeenkomst in voeding tussen familieleden, de invloed van ouders op de voeding van kincleren en de overeenkomsten in voedingsgewoonten binnen bepaalde culturen [Birch \& Fisher, 1996; De Bourdeaudhuïj, 1997; Feunekes, 1996]. Daarnaast zijn er aanwijzingen dat sociale invloeden niet zo expliciet merkbaar zijn bij het bepalen van het huidige voedingsgedrag, maar des te sterker merkbaar worden als je iets aan je voeding wilt veranderen [Brug \& Van Assema, in druk]. Pas als je anders wilt gaan eten, merk je dat je afhankelijk bent van de normen, wensen en gewoonten van mensen in je directe sociale omgeving.

\section{ZIJN DEZE VERWACHTINGEN NU OOK ECHT DETERMINANTEN?}

De gedragstheorieën die ik net aanhaalde, worden beschouwd als determinantenmodellen. Dit veronderstelt dat verschillen in bijvoorbeeld beliefs ten aanzien van vet de oorzaak zijn van verschillen in vetconsumptie. De associaties die zijn gevonden tussen op beliefs gebaseerde determinantenscores 
en intenties om weinig vet te eten dan wel vetconsumptiescores, lijken deze veronderstelling te ondersteunen [Baranowski et al., 1999; Stafleu et al, $1991]^{6}$.

De determinantenstudies zijn echter vijwel zonder uitzondering cross-sectioneel van aard en cross-sectionele studies zijn niet erg geschikt om causaliteit vast te stellen. Er is dan ook een grote behoefte aan longitudinaal en experimenteel determinantenonderzoek. Wij zullen proberen om aan die behoefte te gaan voldoen. In een samenwerkingsproject tussen de capaciteitsgroepen Epidemiologie, GVO en Humane Biologie wordt door collega Rik Bogers een eerste longitudinaal onderzoek naar determinanten van groente- en fruitconsumptie uitgevoerd. Daarnaast zullen we de komende jaren gaan rapporteren over longitudinaal onderzoek naar de determinanten van vetconsumptie op basis van secundaire analyses van bestaande databestanden.

Echt experimenteel onderzoek naar psychosociale determinanten van voedingsgedrag, waarin gedragsdeterminanten in gecontroleerd onderzoek gemanipuleerd worden en waarbij verandering in voedingsgedrag, of motivatie tot een dergelijke verandering, de afhankelijke variabele is, vindt nog veel te weinig plaats. Dergelijk onderzoek kan gecombineerd worden met het experimenteel pretesten van voedingsvoorlichtingsmateriaal. Onder leiding van Zorg-Onderzoek Nederland is enkele maanden geleden gedebatteerd over kwaliteitseisen voor publiekscampagnes. Een van die eisen zou mijns inziens moeten zijn dat de campagnes niet alleen op gedegen determinantenonderzoek zijn gebaseerd, maar dat ook het daarop gebaseerde interventiemateriaal experimenteel wordt getoetst en pas bij bewezen effectiviteit op grote groepen mensen wordt losgelaten. De nu vaak gebruikte pretest waarbij het reeds ontwikkelde materiaal vlak voor de start van de campagne aan enkele leden van de doelgroep wordt voorgelegd om na te gaan of zij het materiaal aantrekkelijk en begrijpelijk vinden, is gewoonweg niet voldoende. Als mensen iets leuk vinden, wil dit nog niet zeggen dat het werkt. Collega Gerjo Kok heeft al voorgesteld om te komen tot een soort testlab en een testprotocol waarbij interventiemateriaal systematisch in randomized controlled trials kan worden getest. Op die manier gaan we werkelijk op weg naar een

\footnotetext{
"Regressie van deze determinanten op intentie of vetconsumptiescores leidt tot $20-50 \%$ veriklaarde wariantie.
} 
"evidence based' voedingswoorlichting. De eerste reacties uit het veld op een pleidooi voor een meer experimentele benadering van de pretestfase in de ontwikkeling van voorlichtingsmateriaal zijn niet alleen positief. Men wil aan de slag en ziet de tijd die gemoeid is met experimenteel onderzoek toch vooral als vertraging. Maar wat zou u denken als een nieuw geneesmiddel alleen gepretest werd door het aan te bieden aan een tiental vijwilligers en dat wanneer zij het nieuwe pilletje er wel mooi uit vonden zien en de verpakking wel apprecieerden, de pil de markt op mag? Natuurlijk gaat deze vergelijking deels mank. Maar er zijn voldoende voorbeelden dat voorlichtingsinterventies die vooraf niet goed getoetst zijn soms behoorlijk desastreuze effecten hadden. Zo gaf Anita Jansen in haar oratie op deze plek nog een voorbeeld van voorlichting over eetproblemen die niet leidde tot minder, maar tot meer probleemgevallen [Jansen, 2000]. Een experimentele pretestfase is bij voedingsvoorlichting juist zo belangrijk omdat bij de implementatie van die voorlichting op grote schaal een valide effectevaluatie meestal niet meer mogelijk is.

Een testfase met experimenteren past, mijns inziens, heel goed in een andere belangrijke ontwikkeling voor een betere afstemming van interventies op de systematische gedrags- en determinantenanalyse: Intervention Mapping. Intervention Mapping is een protocol om theorie en ervaring zo goed mogelijk in te zetten voor de ontwikkeling van gezondheidsbevorderingsinterventies.

Of en in hoeverre dit protocol in de praktijk werkt en of interventies die met behulp van Intervention Mapping zijn ontwikkeld, (kosten)effectiever zijn, moet nog worden bewezen. Marloes Martens is, in het kader van een samenwerkingsproject tussen de capaciteitsgroep GVO, het Voedingscentrum en de Nederlandse Hartstichting, begonnen met de ontwikkeling van een voedingsprogramma voor middelbare scholieren waarbij het programma aan de hand van Intervention Mapping wordt ontwilkkeld. Daarnaast ben ik samen met collega Harm Hospers van de Faculteit der Psychologie, mede op initiatief van de Nederlandse Hartstichting en de onderzoeksschool Vlag, bezig om plannen uit te werken om de mogelijkhederi van preventie van overgewicht te onderzoeken aan de hand van Intervention Mapping.

Naast de bovengenoemde methodologische overwegingen zijn er nog ten minste twee factoren die een directe invloed van beliefs op gedrag in de weg kunnen staan: omgevingsfactoren en gebrek aan bewustzijn van de eigen vetconsumptie. 


\section{Omgevingsfactoren}

Het belang van de hiervoor genoemde belief-gebaseerde determinanten van vetconsumptie kan sterk afhankelijk zijn van de omgeving. In een omgeving waar vetarme voedingsmiddelen niet beschikbaar, bereikbaar of herkenbaar zijn, kunnen mensen nog zulke positieve beliefs ten aanzien van vetarn eten hebben, zonder dat dit resulteert in een lage vetconsumptie. Daarnaast kunnen mensen weinig invloed hebben op wat ze eten omdat ze niet zelf hun woeding kopen en/of bereiden. Dit geldt met name voor jonge kinderen, maar ook nog steeds voor veel keukenschuwe mannen en voor mensen die bijvoorbeeld eten in bedrijfsrestauraties of mensen die in instellingen wonen en eten. Collega Ingrid Steenhuis heeft de afgelopen jaren onderzoek gedaan naar zogenaamde omgevingsinterventies. Zij heeft meer specifiek onderzocht of door het vergroten van de verkrijgbaarheid en herkenbaarheid van gezonde keuzes in supermarkten en bedrijfskantines, de voedselconsumptie van de klanten beïnvloed kan worden [Steenhuis \& Van Assema, 2000].

Omgevingsfactoren lijken met name van groot belang bij de aanpak van overgewicht. De oorzaken van overgewicht lijken duidelijk: een positieve energiebalans. Als mensen meer energie innemen dan besteden, worden ze dikker. Of eten dan wel bewegen het meest bijdraagt tot de obesitasepidemie is onduidelijk. Beide risicogedragingen zijn ook nog niet erg specifiek gedefinieerd. Overeten is een combinatie van te vaak eten, te grote porties, een keuze voor energiedichte voedingsmiddelen, et cetera. Te weinig bewegen is een combinatie van bijvoorbeeld vervoerskeuze, werkomstandigheden en vrijetijdsbesteding. Het is nog niet duidelijk welke gedragsdoelen in potentie het meeste kunnen bijdragen aan het bereiken van een energiebalans.

Nog minder duidelijkheid bestaat over waarom mensen meer eten dan ze verbranden. [Bar-Or, Foreyt, Bouchard, Brownell, Dietz, Ravussin, Salbe, Schwenger, St. Jeor \& Torun, 1998; Birch, 1999; Capaldi, 1996; Drewnowski $\&$ Greenwood, 1983; Hill \& Peters, 1998; Reed, Bachmanov, Beauchamp, Tordoff $\&$ Proce, 1997]. Steeds meer wordt hierbij de nadrulk op omgevingsfactoren gelegd. Met name in de Verenigde Staten zijn de laatste jaren enkele empirisch onderbouwde opinievormende artikelen verschenen waarin een pleidooi wordt gehouden voor een bredere coalitiebenadering in het voorkomen en bestrijden van overgewicht [Battle \& Brownell, 1996; Ernsberger $\&$ Koletsky, 1999; Wooley $\&$ Garner, 19911. In deze artikelen wordt aangegeven 
dat aspecten in onze fysieke, sociale, culturele en economische omgeving een zeer negatieve invloed op een gezonde energiebalans hebben: het aanbod van smakelijk energierijk voedsel is ruim, divers en overal aanwezig; de mogelijkheden om fysieke activiteit tot een minimum te beperken, worden steeds groter en de mogelijkheden voor regelmatige fysieke inspanning steeds kleiner; voeding en met name het eten van energierijke (vette en zoete) voedingsmiddelen staat vaak centraal in sociale en cultureel belangrijke evenementen; energie- en vetarme varianten van gebruikelijke energierijke voedingsmiddelen zijn vaak duurder en minder makkelijk verkrijgbaar. De maatschappij is geëvolueerd naar meer mogelijkheden tot het eten van energiedichte voedingsmiddelen en naar minder mogelijkheden tot bewegen.

De sterk teruggelopen prevalentie van roken in de Verenigde Staten wordt toegeschreven aan de brede 'health promotion' benadering van het probleem: een combinatie van gezondheidsvoorlichting gericht op stoppen met roken en rookpreventie, normverandering, prijsbeleid, en wetgeving, waarbij samengewerkt werd door gezondheidsinstellingen, overheid, industrie en wetenschap. Wanneer de oorzaken wan een gezondheidsprobleem voor een relevant deel in de oingevingsfactoren zijn te vinden, is een dergelijke benadering wellicht essentieel. De effectiviteit van een dergelijke aanpak zou daarom ook voor preventie en bestrijding van overgewicht moeten worden onderzocht. Enig empirisch bewijs dat een dergelijke coalitiebenadering ook potentie heeft voor verandering van voedingsgedrag wordt gevonden in de Let-op-Vet campagnes en de daaropvolgende Goede Voeding campagnes. De daling in vetconsumptie die werd geconstateerd gedurende de campagneperiode, kan worden toegeschreven aan een combinatie van veranderd aanbod van voedingsmiddelen en een gedragsverandering van de Nederlandse bevolking [Hulshof, Löwik $\&$ Kistemaker, 1994]. De plannen die wij uitwerken voor een project gericht op preventie van overgewicht, zullen met name ook deze omgevingsfactoren zo specifiek mogelijk in kaart moeten brengen. Vervolgens moeten we nagaan of op basis van deze omgevingsfactoren haalbare uitgangspunten en doelstellingen kunnen worden geformuleerd voor interventies gericht op de preventie van obesitas.

\section{Bewustzijn van voedingsgedrag en determinanten van verandering}

Voedingsgedrag is principieel verschillend van ander gezondheidsrisicogedrag waar in GVO-land veel aandacht voor is. Laten we een vergelijking maken 
tussen roken en vet eten. Roken is ongezond, hoe minder je rookt hoe beter en de aanbeveling is om niet te roken. Roken is risicogedrag dat uit een beperkt aantal handelingen bestaat: kopen van sigaretten, opsteken, inhaleren et cetera. Roken is ook een duidelijk zichtbaar gedrag. Iedereen weet van zichzelf of hij rookt of niet. Het eten van vet is echter veel gecompliceerder. Stoppen met vet is onwenselijk want wij hebben een bepaalde hoeveelheid vet nodig om gezond te blijven. De aanbeveling is "30 35 energieprocent vet". Dat is voor de gemiddelde consument niet een echt praktisch hanteerbare richtlijn. Vetconsumptie bestaat uit een groot aantal handelingen. Je eet geen vet, zoals je wel een sigaret rookt, maar je eet verschillende voedingsmiddelen in verschillende combinaties die op verschillende wijzen zijn bereid. Die consumptie van een combinatie van voedingsmiddelen bepaalt de vetconsumptie. Omdat vetconsumptie zo diffuus is, weten de meeste mensen helemaal niet hoeveel vet ze eten en onderschatten de meesten hun consumptieniveau. De meeste Nederlanders denken dat zij niet te veel vet en voldoende groente en fruit eten. Uit voedselconsumptieonderzoek blijkt echter het tegenovergestelde. Dit gebrek aan bewustzijn van de eigen voedselconsumptie heeft verstrekkende gevolgen. Men denkt al voldoende gezond te eten en is daarom volstrekt niet gemotiveerd om de eigen eetgewoonten te veranderen. Ons onderzoek heeft duidelijk aangetoond dat het creëren van bewustzijn van de eigen consumptie een eerste noodzakelijke stap is in het proces van gedragsverandering [Brug, Hospers \& Kok, 1997].

Dit gebrek aan bewustzijn heeft nog twee belangrijke consequenties. In de eerste plaats moeten de resultaten van determinantenonderzoek bij populaties die niet weten wat ze eten, zeer voorzichtig worden geïnterpreteerd [Brug, Van Assema, Kol, Lenderink \& Glanz, 1994]. Bij dergelijke populaties blijken attitudes, sociale invloeden en eigen-effectiviteitsverwachtingen samen te hangen met wat men denkt wat men eet, maar niet of nauwelijks met wat men werkelijk eet. Klassieke determinanten als attitudes lijken dus pas relevant te worden nadat mensen bewust zijn van hun eigen, minder gezonde voedingsgewoonten. Ten tweede zorgt het gebrek an bewustzijn ervoor dat er een groot verschil is tussen de determinanten van de huidige voedsellconsumptie en de determinanten van verandering van voedingsgewoonten. Uit ons onderzoek blijkt dat mensen in Nederland bijvoorbeeld veel meer voordelen dan nadelen verwachten van voedsel met weinig vet, zichzelf door hun omgeving gesteund voelen in het eten van weinig vet en 
zichzelf heel goed in staat achten tot het herkennen, kopen, koken en eten van vetarme voeding. Hilermee lijken alle voorwaarden aanwezig voor de promotie van vetarm voedsel. Deze mensen denken echter dat zij al weinig vet eten. Eigenilijk hebben zij gewoon een positieve attitude, positieve eigeneffectiviteitsverwachtingen et cetera, ten aanzien wat zij gewoon zijn te eten, en dat is niet zo verwonderlijk. Wanneer je bij dezelfde mensen de attitude, sociale invloeden en eigen-effectiviteitsverwachtingen gaat meten ten aanzien van 'minder vet eten dan u nu doet', blijken de determinanten opeens veel minder positief [Brug \& Kok, 1995].

\section{CONSEQUENTIES VOOR VOORLICHTINGSINTERVENTIES}

Uit het voorafgaande mag duidelijk zijn geworden dat er geen eenduidig recept is voor voedingsvoorlichting. Wat wel duidelijk is, is dat de voorlichting zo goed mogelijk moet aansluiten bij de belangrijkste determinanten van het specifieke voedingsgedrag waar je als voedingsvoorlichter invloed op wilt uitoefenen [Contento, Balch, Bronner, Lytle, Maloney; Olson \& Swadener, 1995]. En kort samengevat zijn die determinanten als volgt: wat we eten wordt in de eerste plaats sterk bepaald door waar we vroeger aan zijn blootgesteld. Ik denk dat vooral door de aard van die blootstelling in de vroege jeugd een bepaalde bandbreedte is vastgesteld voor wat we door bijvoorbeeld voedingsvoorlichting nog aan voedingskeuze kunnen beïnvloeden. Om voedselkeuzen te beïnvloeden, binnen die hypothetische bandbreedte, geven voorlichters vaak informatie over gezondheidsconsequenties en -risico's. Deze spelen wel een rol in het bepalen van onze voedselkeuze, maar meestal niet een doorslaggevende, ook al omdat mensen vaak helemaal niet bewust zijn van het feit dat ze bijvoorbeeld te veel vet of te weinig groente eten. Een afweging van andere voor- en nadelen, en met name smaakverwachtingen, alsmede inschattingen van hoe moeilijk of makkelijk verandering van voedselgewoonten is, zijn vaak veel belangrijker. Daarnaast speelt de omgeving een belangrijke rol in wat verkrijgbaar en bereikbaar is. Op basis van deze inzichten zijn er verschillende aangrijpingspunten voor voedingsvoorlichting. Voedingsvoorlichting kan, afhankelijk van het doel en het probleem, gericht 
worden op het beïnvloeden van ouders, zodat zij helpen om kinderen vooral bloot te stellen aan gezonde keuzen en zij in ieder geval de voedselkeuzebandbreedte optimaliseren, op bewustmaking van de eigen voedselconsumptie, op het introduceren van voordelen van de gewenste voedselkeuzen en het wegnemen van de nadelen daarvan, op het aanleren of aanreiken van vaardigheden, maar ook op het beïnvloeden van de omgeving om gezond eten smakelijk en makkelijker te maken. We kunnen op basis van recent onderzoek echter nog wel iets specifieker zijn in waar voedingsvoorlichting zich met name op zou moeten richten.

\section{Determinanten en Stages of Change}

Dat gedragsverandering niet een eenstapsproces is dat voor iedereen vrijwel gelijk is, is vooral gecommuniceerd door Prochaska en DiClemente via hun transtheoretisch model en dan met name het zogenaamde stages of changeconcept daaruit [Prochaska et al., 1992]. De belangrijkste implicatie van dit model is dat verandering van voedingsgedrag in goed van elkaar te onderscheiden stappen verloopt: precontemplatie, contemplatie, voorbereiding, actie en gedragsbehoud. Wij hebben onderzoek gedaan naar de integratie van de genoemde belief-gebaseerde determinantenmodellen, de rol van bewustzijn in de motivatie om anders te gaan eten en het stages of change-concept.

Kort samengevat maken we uit dit onderzoek op dat voorlichting voor mensen in precontemplatie vooral moet zijn gericht op bewustmaking, blootstelling aan gezonde voeding, risicopercepties en voordelen van verandering van voedingsgedrag. Interventies voor mensen in de contemplatie- en voorbereidingsfase moet met name gericht zijn op het aanleren van vaardigheden om gezonder te gaan eten, op het bevorderen van vertrouwen dat men gezonder kan eten, op verandering van de omgeving om gezond eten beter mogelijk en makkelijker te maken, op het zichtbaar maken van anderen die het goede voorbeeld geven en op het mobiliseren van sociale steun om de stap naar gezonder eten echt te zetten. Voor mensen in de actiefase, mensen die echt de stap naar gezonder eten hebben gezet, zouden interventies gericht moeten zijn op het geven van zo persoonlijk mogelijke feedback over die gezondere voeding en op het aanleren van vaardigheden om binnen de gezondere keuzen te kunnen variëren, en ook weer op de omgeving zodat vol- 
doende variatie binnen gezonde keuzen beschikbaar is [Van Assema, Brug \& Lechner, in druk].

\section{CRITERIA VOOR EFFECTIEVE INTERVENTIES}

Wanneer men weet wat de oorzaak van een ziekte is, heeft men nog geen medicijn dat werkt, dat makkelijk toegediend kan worden en dat door de patiënt op tijd en in de juiste hoeveelheden gebruikt wordt. Zo is het ook bij voedingsvoorlichting: zelfs als $u$ weet wat de determinanten van vetconsumptie zijn en $u$ ook inzicht hebt in de determinanten van motivatie om minder vet te gaan eten, hebt u nog geen interventie. Inzicht in determinanten moet nog worden omgezet in interventiemethodieken en -technieken en die methodieken en technieken moeten resulteren in specifieke interventiematerialen. Om deze invulling op de empirie te baseren, is nog veel onderzoek nodig.

In 1995 heeft Isobel Contento met een aantal collega's [Contento et al, 1995॥ een themanummer van het Journal of Nutrition Education volgeschreven over de effectiviteit van voedingsvoorlichting. Op basis van hun review van de literatuur kan een eerste inventarisatie gemaakt worden van criteria voor effectieve voedingsvoorlichtingsinterventies: (1) interventies zullen zo goed mogelijk moeten aansluiten bij persoonlijke motivationele factoren van mensen in de doelgroep en zo veel mogelijk persoonlijk relevante informatie geven; (2) interventies moeten bij voorkeur mensen in staat stellen om hun eigen voedingsgedrag te kunnen evalueren; (3) mensen in de doelgroep moeten zo veel mogelijk de kans krijgen om actief in de interventie te participeren. Dit lijstje van criteria is echter nog beperkt en zeer algemeen. Een uitdaging voor de komende jaren is deze lijst uit te breiden en te specificeren tot aanbevolen methodieken en technieken voor specifieke voedingsvoorlichtingsdoelen en doelgroepen.

\section{GEAUTOMATISEERD ADVIES-OP-MAAT}

Eén zo'n techniek verdient in ieder geval nader onderzoek; de laatste jaren wordt steeds meer gebruikgemaakt van informatie- en communicatietechno- 
logie om voedingsvoorlichting zo goed mogelijk af te kunnen stemmen op determinanten van gedrag en gedragsverandering en ook om te voldoen aan de bovengenoemde criteria voor effectieve voedingsvoorlichting. Ik heb het dan over geautomatiseerde voedingsadvies-op-maat of ook wel computer-tailored voedingswoorlichting [De Vries \& Brug, 1999; Hospers, 1989, persoonlijke mededeling]. Bij een advies-op-maat wordt gebruikgemaakt van theoretische en empirische inzichten over determinanten van voedingsgedrag en daarnaast wordt het proces van persoonlijke voedingscounseling geïmiteerd, waarbij de expertise van de counselor is vastgelegd in een geautomatiseerd expertsysteem.

Bij de capaciteitsgroep GVO is zo'n voedingsadvies-op-maat gemaakt waarin de vandaag aan de orde gekomen uitgangspunten voor effectieve voedingsvoorlichting zo goed mogelijk zijn toegepast: het advies was gebaseerd op gedragstheorieën, was afgestemd op de in kaart gebrachte gedragsdeterminanten, hield rekening met stages of change en werd zorgvuldig gepland en geïmplementeerd. Contento's criteria voor effectieve voedingsvoorlichting werden toegepast door een geïndividualiseerd advies te geven waarin respondenten bewustmakende feedback kregen over wat zij zelf aten in vergelijking tot wat zij dachten dat ze aten en in vergelijking tot aanbevelingen en de consumptie van vergelijkbare anderen. Dit advies-op-maat was dan ook een succes. Mensen die het advies-op-maat kregen, reduceerden hun vetconsumptie gemiddeld met ongeveer tien procent tegenover slecht twee procent bij mensen die een algemeen voedingsadvies kregen. Nader onderzoek en onderzoek dat met name in de Verenigde Staten is gedaan, bevestigen de potentie van deze vorm van voorlichting [Brug, Campbell \& Van Assema, 1999]. Dat advies-op-maat vaak beter werkt dan een algemeen voedingsadvies is daarmee vrij zeker, met name voor voorlichting over vet. Het onderzoek naar het advies-op-maat toont mijns inziens aan dat wanneer we inderdaad de empirische inzichten uit het onderzoek naar planmatige GVO toepassen, effectieve voedingswoorlichting wel degelijk mogelijk is.

Het belang van een geautomatiseerd voedingsadvies-op-maat zal in de toekomst alleen maar groter worden. Bijvoorbeeld door de ontwikkelingen in de populatiegenetica wordt het steeds beter mogelijk om risicoschattingen voor verschillende aandoeningen te personaliseren. Als het mogelijk wordt om persoonlijke risicoprofielen vast te stellen, groeien ook de mogelijkheden om mensen een preventief geïndividualiseerd advies te geven. De techniek van 
een geautomatiseerd advies-op-maat helpt om een dergelijke geindividualiseerde aanpak bereikbaair te maken voor grote groepen mensen.

Voedingsadvies-op-maat zal dan ook een belangrijk onderzoeksonderwerp blijven de komende jaren. Collega Anke Oenema heeft het voedingsadvies-opmaat geschilkt gemaakt voor verspreiding via internet en gaat de effectiviteit van het advies via dit kanaal onderzoeken. Het voedingsadvies-op-maat wordt de komende jaren in samenwerking met Ilse de Bourdeaudhuij van de Universiteit in Gent gecombineerd tot een voedings- en bewegingsadvies-op-maat, en zal in onderzoek waarvan Hein de Vries de initiator is, opgenomen worden in een breder leefstijl-advies-op-maat. Daarnaast zullen we proberen om een zogenaamde dismantlingstudie gefinancierd te krijgen om goed na te gaan welke aspecten van het advies-op-maat essentieel zijn voor de effectiviteit.

\section{DANKWOORD}

Ik moet er maar eens mee ophouden. Ik heb het gehad over het belang van de leerstoel, ik heb een poging gedaan om de stand van zaken met betrekking tot het voedingswoorlichtingsonderzoek samen te vatten en ik heb onderzoeksplannen gepresenteerd. Drie kwartier is veel te kort. Ik heb daarom niet meer kunnen doen dan een aantal issues aanstippen. En ik heb lang niet alles kunnen aanstippen. Ik had het bijvoorbeeld nog willen hebben over de matige onderzoeksinstrumenten waarmee wij meestal moeten werken en het onderzoek dat wij doen om die instrumenten te verbeteren, over de plannen om onderzoek te starten op het terrein van patiëntenvoedingsvoorlichting en met name clieettrouw, ik had eigenlijk uitgebreider in willen gaan op de uitdagingen voor voedingsvoorlichting in de toekomst van functional foods, genetische counseling en nieuwe productietechnieken die de aard van de voedingsvoorlichting wel eens geheel kunnen gaan veranderen, ik had nog graag een pleidooi gehouden voor meer onderzoek naar de implementatie en disseminatie van effectief gebleken voedingsvoorlichtingsinstrumenten, en ik had graag het belang van het Hartslag Limburg project voor dit soort onderzoek willen noemen. Maar de receptie wacht, en ik begin zelf ook een droge keel te krijgen. Ik hou er dus maar mee op, maar niet voordat ik nog wat mensen bedank. 
De eerste keer dat ik hoorde van de plannen voor een leerstoel voedingsgedrag was in 1994. Destijds mocht ik uit naam van Gerjo Kok een concept wan het structuurrapport nog van enig commentaar voorzien. $\mathbb{k} k$ weet nog goed dat ik toen ambivalente gevoelens had met betrekling tot die leerstoel. Aan de ene kant was ik zeer verheugd dat het Voedingscentrum en de NVPG het belang erkende van sociaal-wetenschappelijk voedingsonderzoek en dit onderzoek middels een leerstoel wilde stimuleren. Anderzijds vond ik dat die leerstoel destijds veel te vroeg kwam, niet woor het vakgebied, maar voor mijzelf. Destijds was ik net halfweg met mijn proefschrift. Ik neem aan dat men bij de Universiteit Maastricht, het Voedingscentrum en de NVPG ook een gedegen langetermijnbeleid voor ogen hadden, want de werving voor de leerstoel liet nog enige tijd op zich wachten, en toen de vacatureadvertentie in november 1998 verscheen, had ik wel de moed of de arrogantie te denken dat ik die leerstoel een goede invulling zou kunnen geven. En dat ga ik de komende jaren doen.

Ik wil een aantal mensen en organisaties bedanken voor hun rol in mijn professionele ontwikkeling.

In de eerste plaats het Voedingscentrum, de NVPG, en de Faculteit der Gezondheidswetenschappen en het College van Bestuur van de Universiteit Maastricht voor het creëren van de leerstoel en het in mij gestelde vertrouwen. Dat ik hier nu voor u sta, is een resultante van een proces dat de afgelopen vijftien jaar heeft plaatsgevonden en waar verschillende personen een belangrijke rol in hebben gespeeld. Zo was er vrouw met hond die aan de wieg stond van een chronische enkelblessure, waardoor ik besloot om toch mijn studie voeding te voltooien en niet mij volledig op de triathlon te richten. Dat ik vervolgens het voedingsonderzoek ben gaan waarderen heb ik met name te danken aan Frans Kok en Michiel Löwik. Door de kansen en begeleiding die zij mij destijds bij TNO-Voeding gaven, ben ik de lol van wetenschappelijk onderzoek en het daarover publiceren, gaan inzien. Vervolgens gaf de Nederlandse Kanker Bestrijding mij de mogelijkheid om mij te specialiseren in sociaal-wetenschappelijk voedingsonderzoek. De capaciteitsgroep GVO biedt mij nu het intellectuele en het vriendschappelijke klimaat om met overgave en plezier mijn werk als bijzonder hoogleraar te doen. Een aantal van $\mathbf{u}$ zal zijn opgevallen dat de naam van Patricia van Assema, mijn meest gewaardeerde collega bij de capgroep GVO, nog niet is gevallen. Dit komt omdat ik haar naam dan wel kon blijven herhalen; zij is bij vrijwel elk onderzoek of onderzoeksplan betrokken en ik hoop nog jaren met 
haar op die manier te bijiven samenwerken. Gerjo Kok"s naam is al wel eerder gevallen. Hij is voor mij een belangrijk mentor geweest. Van het onderzoeksinstituut Nutrim wil ik met name Wim Saris en wijlen Foppe ten Hoor bedanken, omdat zij er voor gezorgd hebben dat er naast Wageningen in Nederland nog een belangrij $k$ universitair centrum voor voedingsonderzoek is gekomen en dat we nu weer samen met Wageningen in een vooraanstaande onderzoeksschool participeren. Dank is ook zeker verschuldigd aan de financiers van het onderzoek dat vandaag genoemd is of dat door tijdgebrek niet genoemd kon worden. In willekeurige volgorde: de Nederlandse Kanker Bestrijding, de Nederlandse Hartstichting, Zorgonderzoek Nederland, en het Ministerie van Landbouw. Tot slot wil ik alle collega's in het gedragswetenschappelijk voedingsonderzoek, die zich voor een groot deel hebben verenigd in de Werkgroep Voedingsgewoonten, bedanken voor de prettige samenwerking en stimulans.

Ik dank $u$ voor uw aandlacht. 


\section{REFERENTIES}

Ajzen, I. (1991). The theory of planned behavior Organizational Behavior and Human Decision Processes, 50, 179-211.

Bandura, A. (1986). Social foundations of thought and action. A social cognitive theory. Englewood Cliffs, NJ: Prentice Hall.

Bandura, A. (1999). Self-efficacy: The exercise of control New York: Freeman and Company.

Baranowski, I, Cullen, KW., \& Baranowski, J. (1999). Psychosocial correlates of dietary intake: Advancing dietary intervention. Annual Reviews of Nutrition, 19, $17-40$.

Bar-Or, O., Foreyt, J., Bouchard, C., Brownell, K.D., Dietz, W.H., Ravussin, E., Salbe, A.D., Schwenger, S., St. Jeor, S., $\&$ Torun, B. (1998). Physical activity, genetic, and nutritional considerations in childhood weight management.

Medical Science in Sports and Exercise, 30, 2-10.

Bartholomew, K., Parcel, G., Kok, G., \& Gottlieb, N. (2000). Intervention Mapping; developing theory-and evidence-based health education programs. Mountain View, CA: Mayfield.

Battle, E.K., \& Brownell, K.D. (1996). Confronting a rising tide of eating disorders and obesity: Treatment vs. prevention and policy. Addictive Behaviors, 21, 755-765.

Birch, LL. (1999). Development of food preferences. Annual Reviews of Nutrition, 19, $41-62$.

Birch, L. L. \& Fisher, J.A. (1996). The role of experience in the development of children's eating behavior. In E.D. Capaldi (Ed.), Why we eat what we eat: The psychology of eating (pp. 113-144). Washington, DC: American Psychological Association.

Block, G., Patterson, B., \& Subar, A. (1992). Fruit, vegetables, and cancer prewention: A review of the epidemiological evidence. Nutrition and Cancer, 18, 1-29.

Brug, J., Campbell, M., \& Van Assema, P. (1999). The application and impact of computer-generated personalized nutrition education: A review of the literature. Patient Education and Counseling, 36, 145-156.

Brug: J., Debie, S., Van Assema, P. \& Weijts, W. (1995). Psychosocial determinants of fruit and vegetable consumption among adults. Results of focus group interviews. Food Quality and Preference, 6, 99-107.

Brug, J., Hospers, H., \& Kok, G. (1997). Differences in psychosocial factors and fat consumption between stages of change for fat reduction. Psychology and Health, 12, 719-727.

Brug, J., \& Kok, G. (1995). Misconceptie van consumenten over eigen vetconsumptie. Voeding, 56, 11-14.

Brug, J., Lechner, L., \& De Vries, H. (1995). Psychosocial determinants of fruit and vegetable consumption. Appetite, 25, 285-296. 
Brug, J., Riedstra, M, Pruyn, J.EA, \& Aarnink, E.J.M. (1993). De effecten van de derde landelijke Let op Vet campagne, gehouden in 1993. Consumenten onderzoek. Zeist: TNO rapport, V93,365.

Brug. J., Schaalma, H., Kok, G., Meertens, R., \& Van der Molen, H.I (Red.) (2000). Gezondheidswoorlichting en gedragsverandering: Een planmatige aanpak. Assen: Van Gorcum.

Brug, J., Van Assema, P. \& Kok, G.J. (1995). Psychosocial determinants of dietary fat intake and intention to change. Ernährungs-Umschau, 42, 150-152.

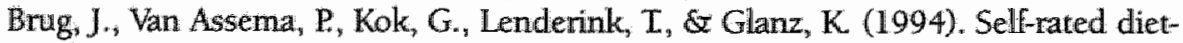
ary lat intake: Associations with objective assessments of fat, psychosocial factors and intention to change. Journal of Nutrition Education, 26, 218-223.

Campbell, M., DeVellis, B.M., Strecher, VJ., Arnmerman, A.S., DeVellis, R.F., \& Sandler, R.S. (1994). Improving dietary behavior: The effectiveness of tailored messages in primary health settings. American Journal of Public Health, 84, 783787.

Capaldi, E.D. (1996). Conditioned food preferences. In E.D. Capaldi (Ed.), Why we eat what we eat: The psychology of eating (pp. 53-82). Washington, DC: American Psychological Association.

Contento, I., Balch, G.I., Bronner, Y.L., Lytle, L.A., Maloney, S.K., Olson, C.M., \& Swadener, S.S. (1995). The effectiveness of nutrition education and implications for nutrition education policy, programs and research: A review of research. Journal of Nutrition Education, 27, special issue.

De Bourdeaudhuij, 1. (1997). Perceived family members' influence on introducing healthy food into the family. Health Education Research, 12, 77-90.

De Vries, H., \& Brug. J. (1999). Computer-tailored interventions motivating people to adopt health promoting behaviours: Introduction to a new approach. Patient Education and Counseling, 36, 99-105.

De Vries, H., Dijkstra, M., \& Kuhlman, P. (1988). Self efficacy: The third factor besides attitudes and subjective norm as a predictor of behavioral intentions. Health Education Research, 3, 273-282.

Drewnowski, A, \& Greenwood, M.R.C. (1983). Cream and sugar: Human preferences for high-fat foods. Physiology and Behavior, 30, 629-633.

Emsberger, , \& Koletsky, RJ. (1999). Biomedical rationale for a wellness approach to obesity: An alternative to a focus on weight loss. Journal of Social Issues, 55, $221-260$.

Feunekes, G. (1996). Food, fat, family $E$ friends: Studies on the impact of the social environment on dietary intake. Wageningen, the Netherlands: Landbouwuniversiteit. Glanz, KK, Basil, M., Maibach, E., Goldberg, J., \& Snyder, D. (1998). Why Americans eat what they do: Taste, nutrition, cost, convenience, and weight control concerns as influences on food consumption. Journal of the American Dietetic Association, 98, 1118-1126. 
Glanz, $\mathbb{K}, \&$ Rudd, J. (1993). Views of theory, research, and practice: A survey of nutrition education and consumer behavior professionals. Journal of Nutrition Education, 25, 270-273.

Godin, G., \& Kok, G. (1996). The theory of planned behavior: A review of its applications to health-related behaviors. American Journal of Health Promotion, $11,87-98$.

Gofton, L. (1996). Food fears and time famines. In E.D. Capaldi (Ed.), Why we eat what we eat: The psychology of eating (pp. 233-266). Washington, DC: American Psychological Association.

Green, L.W. \& Kreuter, M.W. (1999). Health promotion planning: An educational and ecological approach. Mountain View "CA: Mayfield.

Grivetti, L.E. (1997). Social determinants of food intake. In G.H. Anderson, B.J.

Rolls \& D.G. Steffen, Nutritional implications of macrorutrient substitutes (pp.

121-131). New York: New York Academy of Sciences.

Hepper, D.G. (1988). Adaptive fetal learning: Prenatal exposure to garlic affects postnatal preferences. Animal Behavior, 36, 935-936.

Hill, J.O., \& Peters, J.C. (1998). Environmental contributions to the obesity epidemic. Science, $280,1371-1374$.

Hulshof, K.F.A.M., Löwik, M.R.H., \& Kistemaker, C. (1994). Voeding na vijf jaar opnieuw gepeild. Voeding, 55, 28-32.

Jansen, A. (2000). Over lust en schoonheid: Pleidooi voor een spaarzame verklaring van eetstoomissen (oratie). Universiteit Maastricht.

Keenan, D.P., AbuSabha, R., Sigmant-Grant, M., Achterberg, C., \& Ruffing „』.

(1999). Factors perceived to influence dietary fat reduction behaviors. Journal of Nutrition Education, 31, 131-144.

Kok, G., De Vries, H., Mudde, A.N., \& Strecher, VJ. (1991). Planned health education and the role of self-efficacy: Dutch research. Health Education Research, 6, 231-238.

Kok, G., Schaalma, H., \& Brug, J. (2000). Planmatige gezondheidsvoorlichting: Een inleiding. In J. Brug, H. Schaalma, G. Kok, R. Meertens \& H.T van der Molen (Red.), Gezondheidswoorlichting en gedragsverandering: Een planmatige aanpalt. Assen: Van Gorcum.

Kok, G., Schaalma, H., De Vries, H., Parcel, G., \& Paulussen, I (1996). Social psychology and health education. In W. Stroebe \& M. Hewstone (Eds.), European Review of Social Psychology (Vol. 7) (pp. 241-282). New York: Willey.

Mennella, J.A. \& Beauchamp, G.K. (1996). The early development of human thavour preferences. In E.D. Capaldi (Ed.), Why we eat what we eat: The psychology of eating (pp. 233-266). Washington, DC: American Psychological Association. Prochaska, J.O., DiClemente, C.C., \& Norcross, J.C. (1992). In search of how people change: Applications to addictive behaviors. American Psycholo-gist, 47, $1102-1114$.

Pliner, P. \& Hobden, K (1992). Development of a scale to measure the trait of food neophobia in humans. Appetite, 19, 105-120. 
Reed, D.R., Bachmanov, A.A., Beauchamp, G.K. Tordof, M.G., \& Proce, RA.

(1997). Heritable variation in food preferences and their contribution to obesity.

Behavior Genetics, 27, 373-387.

Rozin, P. (1996). Sociocultural influences on human food selection. In ED. Capaldi

(Ed.), Why we eat what we eat: The psychology of eating (pp. 233-266).

Washington, DC: American Psychological Association.

Ruiter, R.A.C., Kok, G., \& Abraham, C. (in voorbereiding). Scary wamings and

rational precautions: A review of the operation of fear appeals in promoting self-

protective behaviour.

Seidell, J. (1997). Lichaamsgewicht. In L.A.M. Maas, R. Gijsen, I.E. Lobbezoo, \&

M.J.J.C. Poos, Volksgezondheid Toekomstverkenningen 1997. De gezondheidstoe-

stand: Een actualisering (pp. 654-661). Maarsen: Elsevier/De Tijdstroom.

Stacey, M. (1994). Why Americans love, hate and fear food. New York: Touchstone.

Stafleu, A., De Graaf, C., Van Staveren, W.A., \& De Jong, M.A.J.G. (1991). A review

of sellected studies assessing social-psychological determinants of fat and cho-

lesterol intake. Food Quality and Preference, 3, 183-200.

Steenhuis, I., Molenaar, E., Van Assema, R, Brug, J., \& Mela, D. (in voorbereiding).

Het effect van het gratis aanbieden van gezonde voedingsmiddelen in bedrijfsrestaurants.

Steenhuis, 1., \& Van Assema, P. (2000). In J. Brug, H. Schaalma, G. Kok, R.

Meertens \& H.I van der Molen, Gezondheidswoorlichting en gedragswerandering:

Een planmatige aampak. Assen, the Netherlands: Van Gorcum.

Van Assema, P., Brug, J., \& Lechner, L. (in druk). Voedingsgedrag en primaire preventie van kanker: De promotie wan groente en fruit. Tijdschrift Gezondheidswetenschappen.

Van Assema, P, Glanz, K., Brug, J , \& Kok, G. (1996). Effects of health claims on eating habits of the Dutch population. European Journal of Public Health, 6, 281287.

Van Wechem, S.N., Brug, J., Van Assema, P, Kistemaker, C., Riedstra, M., \& Löwik, M.R.H. (1998). Fat Watch: A nationwide campaign in the Netherlands to reduce fat intake. Effect evaluation. Nutrition and Health, 12, 119-130.

Westenhoefer ${ }_{i} J$., \& Pudel, V (1993). Pleasure from food: Importance for food choice and consequences of deliberate restriction. Appetite, 20, 246-249.

Willett, W.C. (1994). Diet and health: What should we eat? Science, 264, 532-537.

Wooley, S. C., \& Garner, D.M. (1991). Obesity treatment: The high cost of false

hope. Journal of the American Dietetic Assaciation, 91, 1248-1251.

Zo eet Nederland (1998). Den Haag: Voedingscentrum. 